\title{
Comparative Prevalence of Intestinal Helminths in Satar and Chaudhary Communities of Birtamode Municipality, Jhapa, Nepal
}

\author{
Shanti Chaudhary and Janak Raj Subedi* \\ Central Department of Zoology, Tribhuvan University, Kathmandu, Nepal.
}

\begin{abstract}
Introduction: Intestinal parasitic infections remain a major public health problem in many parts of the world, particularly in low and middle-income countries like Nepal.

Materials and Methods: The different ethnic groups are geographically, socio-economically, culturally, and genetically diverse and their heterogeneity needs explanation to understand the variation in the prevalence of IPIs among them. The aim of this study was to compare the prevalence of intestinal helminths in Satar and Chaudhary communities of Birtamode Municipality and to identify the risk factors associated with either of them. A total of 220 stool samples, 110 from each community were collected and examined by unstained and stained smear preparation, floatation, and sedimentation technique. A set of questions regarding the risk factors of parasitosis was filled by interviewing each respondent. R-version 1.1.463 was used to perform the chi-square test for statistical analysis of data, and $95 \%$ confidence interval and $\mathrm{P}<0.05$ were considered statistically significant.
\end{abstract}

Results: The overall prevalence of infection was found 28.63\%. A significant difference was seen in the prevalence of parasites between Satar and Chaudhary communities $(\mathrm{p}<0.05)$. The age-wise prevalence revealed a high rate of infection among children, followed by old age and adults, while sex-wise prevalence showed marginally higher infection in males in both communities. Altogether six types of parasites were encountered; A. lumbricoides (13.18\%) was the most prevalent parasite. In risk factor analysis, significant associations were seen between parasitic infections and handwashing habits, use of handwashing agent, defecation site preference, and barefoot walking habit in the Satar community. Similarly, a significant association of parasitic infection with handwashing habits and barefoot walking habits were seen in the Chaudhary community.

Conclusion: Hence, a remarkable prevalence of parasitic infection was indicated by the present study. Improvements in personal hygiene, environmental sanitation, provision of sanitary toilets, provision of awareness programs, and preventive measure implementation are important to overcome the parasitic infection in these communities.

Keywords: Prevalence, Parasitosis, IPIs, NTDs, KAP, Helminth, Nematode, Cestode.

\section{INTRODUCTION}

Different species of helminths are capable of causing intestinal parasitic infections (IPIs) [1]. They belong to the neglected tropical diseases (NTDs). The four major nematode species of humans that are capable of causing IPIs are Ascaris lumbricoides, Trichiuris trichura, Ancylostoma duodenale, and Necator americanus; little is known about the burden of disease due to cestodes [2]. Above 3 billion people worldwide are suffering from severe helminth infections leading to morbidity and more than 150,000 annual deaths [3]. According to World Health Organization, more than $24 \%$ of the people worldwide are infected with IPIs; the majority of them are residence of developing countries [4]. The major health issues caused by IPIs are a negative effect on nutritional status, physical growth and cognitive development of host and can even lead to high levels of morbidity and mortality $[1,2$, $5]$.

*Address correspondence to this author at the Central Department of Zoology, Tribhuvan University, Kathmandu, Nepal.

E-mail: janzoology@gmail.com

doi.org/10.21089/njhs.51.0004

(C) 2020 NIBD Publications
Generally, the prevalence of various species of gastrointestinal parasites varies in different regions because of varying environmental, social, and geographical factors [6]. Hence, studies on the prevalence of IPIs are important to identify specific risk factors and the formulation of appropriate control strategies [7]. Studies in different parts of the world have revealed that age $[8,9]$, source of drinking water $[10,11]$, gender [12, 13], contact with animals [14], and seasonal variations [15] are major risk factors in the transmission of parasitic infections. The indigenous population's epidemiology of IPIs has been extensively studied, with the prevalence rate ranging from $52.4 \%$ to $98.4 \%[11,16-19]$. The different ethnic groups are geographically, socio-economically, culturally, and genetically diverse [20,21], and their heterogeneity need to be examined to understand the variation in the prevalence of IPIs among them. Despite socioeconomic development and demographic changes in Nepal over decades, IPIs are still highly endemic, especially among indigenous communities [22-24]. The most common intestinal parasites infecting various indigenous communities in Nepal reported are Ascaris lumbricoides, Trichiuris trichura, Ancylostoma 
duodenale, Strongyloides stercoralis, Taenia sp., Hymenolepis nana, Cyclospora cayetanensis, Entamoeba histolytica, Giardia lambia [22, 25-27]. There is little information about Nepal's profiles of infection severity and underlying risk factors. To fill this gap, a cross-sectional study was carried out in Satar and Chaudhary communities of Birtamode Municipality, Jhapa district. The study aimed to compare the prevalence of intestinal helminths in two communities and to identify the underlying risk factors in either of them.

\section{MATERIALS AND METHODS}

\section{Study Area}

Birtamode municipality (Fig. 1) is one of the municipalities of Jhapa, Nepal. The total area of the municipality is 78.24 sq. $\mathrm{km}$. The population was 80,592 in 2011, and major ethnicities living there are Rajbanshi, Limbu, Rai, Tajpuriya, Newar, Brahmins, Chhettri, etc. Majority of people are Hindus, others include Muslims, Buddhists and Christians. The climate in the area is very hot and humid during summer, and mild and dry during winter. Temperature reach up to $40^{\circ} \mathrm{C}$ during in summer, and low in winter is about $2^{\circ} \mathrm{C}$. Rainfall is abundant during monsoon, while there is little or no rainfall during winter. The two wards 7 and 9 of Birtamode municipality were chosen as study sites; ward 7 for Satar community and ward 9 for Chaudhary community.

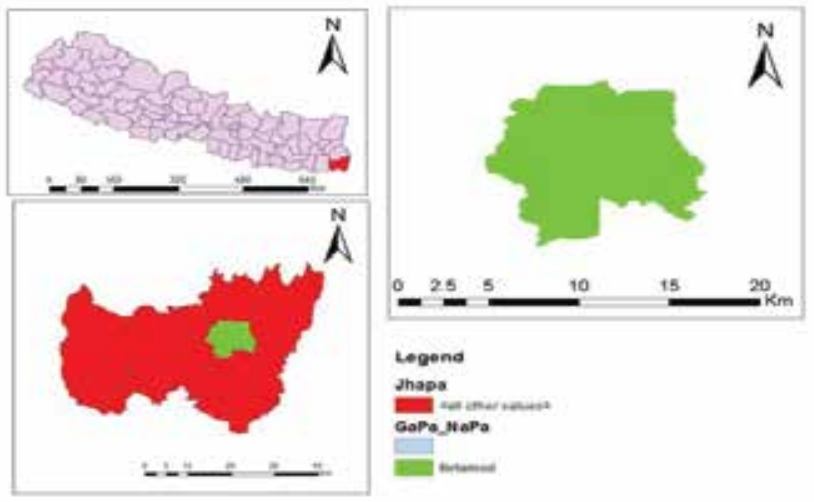

Fig. (1). Map of Birtamode Municipality.

\section{Study Population}

The variation in social, ethical and cultural diversity exhibits variation in various infectious diseases including IPIs [28]. Satar and Chaudhary communities of Birtamode Municipality, Jhapa, are two indigenous communities living in this region having different cultural and living practices. Satar is one of the highly marginalized castes of Nepal having a total population of 25,540 [29], with most of the population residing in the eastern region (19,322 in Jhapa district). Most of the Satar people are illiterate and have very low economic status. Their main occupations are farming, tea plucking, and they also work as laborers in construction sites and transport businesses. They do hunting and fishing and have rat meat and pork eating habit. Poor hygiene practices in them such as open place defecation, barefoot walking habit, and poor sanitation may lead to a high prevalence of intestinal parasite infection. Chaudhary community on the other hand has a total population of $1,737,470$ with 9,909 (1.53\%) people residing in the Jhapa district. They have relatively high education levels and economic status compared to the Satar community; however, some are still under the line of poverty (NPR 12,000 per capita annual income) (http://www.thepovertyline.net/nepal). They are mostly engaged in agricultural fields, and some also work at qualified jobs. Variations in living habits and personnel hygiene practices in these two communities may predispose them to different parasitic infections.

\section{METHODS}

\section{Sample Size and Sample Collection Method}

The baseline cross-sectional study was conducted in the study area. A total of 220 stool samples, 110 from each community were randomly collected. For the collection of the sample, a pre-labeled plastic container was provided to each of the respondents along with specific information on not mixing their urine in stool samples. The stool samples were collected the following day after the completion of the questionnaire survey. Collection of samples was done in the morning time when all people were available. A set of pre-tested and administered, a semi-structured question was filled interviewing each respondent. The question set included demographic data (age, sex, occupation) and information regarding knowledge, attitude, and practice (KAP) of the study population that are regarded as risk factors in the transmission of parasites. The various KAP related factors included were their education, economic status, knowledge about the parasites and their transmission, opinion on whether dirty water cause infection or not, why to wash hands with soap, handwashing habit before and after the meal, after defecation, use of handwashing agent, drinking water quality, defecation site preference, the habit of walking barefoot, raw vegetables and raw or undercooked meats eating habits.

\section{Preservation of Samples}

The collected stool samples were preserved in $2.5 \%$ potassium dichromate solution that helps in maintaining the morphology of parasites and preventing further development of helminth eggs and larvae.

\section{Microscopic Examination}

Microscopic examinations of stool samples were carried out at the laboratory of the Central Department of Zoology, Tribhuvan University, Kathmandu. The samples were processed for microscopic examination using saline and iodine wet mount, floatation, and sedimentation techniques [30]. 


\section{Calibration of Eggs}

The calibration factors for the measurement of eggs sizes are: Calibration Factor $(\mathrm{CF})$ for $10 \mathrm{x}=10.37 \mu \mathrm{m}$

Calibration Factor $(\mathrm{CF})$ for $40 \mathrm{x}=2.58 \mu \mathrm{m}$

\section{Identification of the Eggs}

The identification and confirmation of the eggs found were made by comparing the structure, color, and size of eggs from the book and online reviews [30-32].

\section{Data Analysis}

The data collected from field surveys and laboratory reports were managed according to age, sex, and prevalence of specific intestinal parasites. Chi-square tests (sample proportion test and Fisher's exact test) were performed using R-studio version 1.1.463 to analyze the significance of data at $95 \%$ confidence interval and $\mathrm{P}<0.05$.

\section{RESULTS AND DISCUSSION}

Intestinal parasitic infections are endemic worldwide and constitute a major public health problem in developing coun- tries like Nepal. A remarkable prevalence of intestinal parasitic infection was indicated by the present study carried out among Satar and Chaudhary communities of Birtamode municipality, Jhapa. The study showed an overall prevalence of $28.6 \%$. The prevalence is higher than in some other studies $[24,33,34]$. It is lower than that reported earlier in both national and international scenarios [35-41]. These differences in the results might be due to the place and time differences of the study. A significantly high prevalence of parasite was encountered in the Satar community $(\mathrm{P}<0.05)$ which might be due to lack of awareness and lack of sanitary toilets.

\section{Age-wise and Sex-Wise Prevalence of Parasites}

Age-wise, the intestinal parasitosis was found highest among children, followed by old age and adults in both communities (Table 1). Similar results were reported by some authors $[25$, $34,37,42]$, however, others reported more infected adults [22-24, 38, 43]. There was no significant difference in IPIs among these three groups of both communities. The high parasitic infection found among children in the study population might be due to poverty, illiteracy, lack of awareness, unhygienic behavior, and lack of sanitation.

Table 1. Age-wise Prevalence of Parasites.

\begin{tabular}{|l|c|c|c|c|c|c|c|}
\hline \multirow{2}{*}{ Age groups } & \multicolumn{5}{|c|}{ Communities } & $\begin{array}{c}\text { Overall } \\
\text { prevalence n (\%) }\end{array}$ \\
\hline & \multicolumn{3}{|c|}{ Satar } & \multicolumn{3}{c|}{ Chaudhary } & \\
\cline { 2 - 8 } & $\begin{array}{c}\text { Total cases } \\
\text { N }\end{array}$ & $\begin{array}{c}\text { Positive case } \\
\text { n (\%) }\end{array}$ & P-value & $\begin{array}{c}\text { Total cases } \\
\text { N }\end{array}$ & $\begin{array}{c}\text { Positive case } \\
\text { n (\%) }\end{array}$ & P-value & \\
\hline Children (1-15) & 51 & $20(39.21)$ & & 34 & $10(29.41)$ & & $30(35.29)$ \\
\hline Adults (16-60) & 50 & $15(30.00)$ & 0.62 & 69 & $13(18.84)$ & 0.45 & $28(23.53)$ \\
\hline Old age (Above 60) & 9 & $3(33.33)$ & & 7 & $2(28.57)$ & & $5(31.25)$ \\
\hline
\end{tabular}

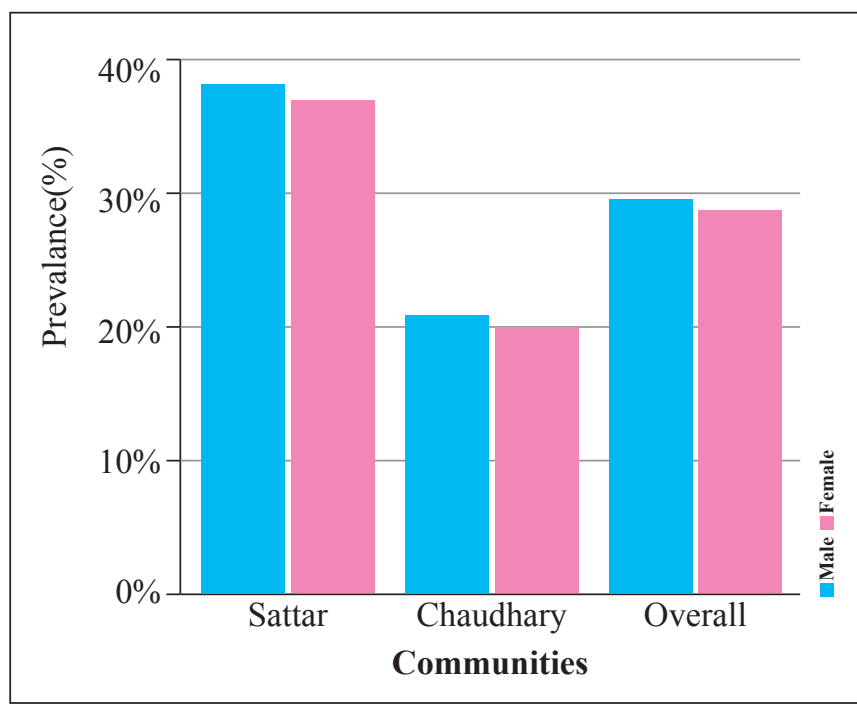

Fig. (2). Sex-wise Prevalence of Parasites.
Sex-wise, the parasitic infection was marginally higher in males $(29.73 \%)$ compared to females $(27.52 \%)$ (Fig. 2$)$. The finding is similar to the results of other studies on the general population in Nepal and other countries [1, 43-48]. A different result was found in a research, which revealed more number of infected females than males [37]. Statistically, no significant difference was found in the prevalence of intestinal parasitic infection between males and females of both communities. Such results were also found in many studies of Nepal [49-53] and elsewhere too [54]. So, the present study showed agreement with others' work, which shows gender independence of parasitic infections [43, 55-58].

\section{Prevalence of Specific Intestinal Parasites}

Regarding specific parasite prevalence, the rate of infection was higher for nematodes compared to cestodes (Table 2). In the (Fig. 3), A. lumbricoides (Fig. 3A) was the most prevalent helminth encountered. Similar results were observed in the works of other parasitologists [22-24, 26] that showed a high 
prevalence of A. lumbricoides. This high helminthic infection, particularly of A. lumbricoides followed by T. trichura (Fig. 3B) in study area might be due to poor hygiene conditions and lack of awareness among the villagers [42, 43, 45 59]. A. lumbricoides eggs can survive a long time in the environment due to presence of chitin in the shell. This might be the reason that its prevalence rate is higher among all other soil transmitted helminths. Some other studies showed a higher prevalence of helminths with most common parasites such as T. trichiura
[53, 60, 61] and Hookworms [62, 63]. Hookworm (Fig. 3C) and S. stercoralis (Fig. 3D) infections were also recorded in the present study that might be related to poor people residing in the locality who usually walk and work barefoot in the soil that might be contaminated with an infective stage of hookworm. Infection with cestodes like Taenia sp. (Fig. 3E) and $H$. nana (Fig. 3F) were very low which might be related to the limited access of meats in poor populations.

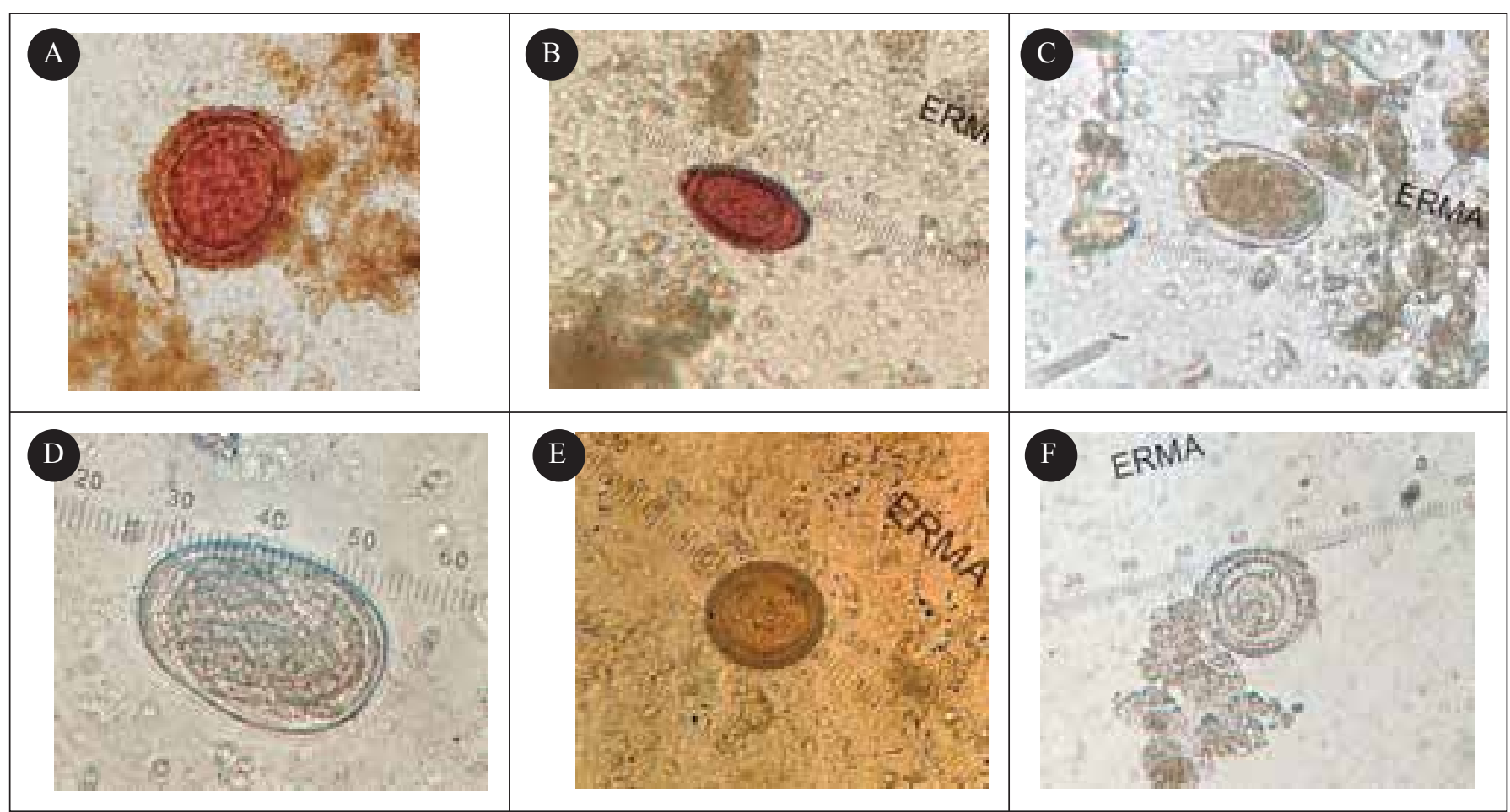

Fig. (3). Images of the eggs of parasites are capture through electronic compound microscope and measure with the help of ocular and stage micrometer. (Fig. 3A), Egg of A. lumbricoides $(60 \times 50 \mu \mathrm{m})$ (Fig. 3B), Egg of T. trichura $(56 \times 25 \mu \mathrm{m})($ Fig. 3C), Egg of Hookworm $(65 \times 40 \mu \mathrm{m})$ (Fig. 3D) Egg of S. stercoralis $(69 \times 35 \mu \mathrm{m})($ Fig. 3E) Egg of Taenia sp. (36 $\mu \mathrm{m})$ (Fig. 3F) Egg of H. nana $(53 \mu)$.

Table 2. Prevalence of Specific Intestinal Parasites.

\begin{tabular}{|l|c|c|c|}
\hline Parasites & \multicolumn{2}{|c|}{ Communities } & $\begin{array}{c}\text { Overall } \\
\text { Prevalence }\end{array}$ \\
\hline & $\begin{array}{c}\text { Satar n } \\
(\%)\end{array}$ & $\begin{array}{c}\text { Chaudhary } \\
\mathbf{n}(\%)\end{array}$ & \\
\hline Nematodes & $17(15.45)$ & $12(10.90)$ & $29(13.18)$ \\
\hline Ascaris lumbricoides & $17.18)$ & $7(6.36)$ & $16(7.27)$ \\
\hline Trichiuris trichura & $9(8.14)$ & $14(6.36)$ \\
\hline Hookworm & $9(8.18)$ & $5(4.54)$ & $5(2.27)$ \\
\hline Strongyloides stercoralis & $3(2.73)$ & $2(1.82)$ & \\
\hline Cestodes & $2(1.82)$ & $2(1.82)$ & $4(1.82)$ \\
\hline Taenia sp. & $3(2.73)$ & - & $3(1.36)$ \\
\hline Hymenolepis nana
\end{tabular}

\section{Risk Factors Associated with Intestinal Parasitic Infection}

For risk factor analysis, sample proportion test and fisher's exact test were performed to show the association of various KAP indicators with the prevalence of parasites (Table 3). In this study, handwashing habits after defecation, use of handwashing agent, defecation site preference, and barefoot walking habit were seen to be major risk factors $(\mathrm{P}<0.05)$ in the Satar community. Similarly, hands washing habits after defecation and barefoot walking habit were found as major risk factors $(\mathrm{P}<0.05)$ in the Chaudhary community.

Proper handwashing habit using soap after defecation can prevent a person from infection of parasites that makes their passage through the oral route. On the handwashing habit after defecation, a significantly high prevalence of parasite was seen among people who do not wash their hands after 
Table 3. Various KAP Indicators and their Association with Prevalence of Parasites.

\begin{tabular}{|c|c|c|c|c|c|c|}
\hline \multirow{3}{*}{ KAP indicators } & \multicolumn{6}{|c|}{ Communities } \\
\hline & \multicolumn{3}{|c|}{ Satar } & \multicolumn{3}{|c|}{ Chaudhary } \\
\hline & Total & $\begin{array}{c}\text { Prevalence } \\
\text { n (\%) }\end{array}$ & P-value & Total & $\begin{array}{c}\text { Prevalence } \\
\text { n (\%) }\end{array}$ & P-value \\
\hline $\begin{array}{l}\text { Education Status } \\
\text { Literate } \\
\text { Illiterate }\end{array}$ & $\begin{array}{l}40(36.4) \\
70(63.6)\end{array}$ & $\begin{array}{l}13(32.5) \\
25(37.7)\end{array}$ & 0.89 & $\begin{array}{l}60(54.5) \\
50(45.5)\end{array}$ & $\begin{array}{l}18(30.0) \\
20(40.0)\end{array}$ & 0.36 \\
\hline $\begin{array}{l}\text { Economic status } \\
\text { Low class } \\
\text { Middle class }\end{array}$ & $\begin{array}{l}82(74.5) \\
28(25.5)\end{array}$ & $\begin{array}{l}29(35.3) \\
9 \quad(32.1)\end{array}$ & 0.93 & $\begin{array}{l}50(45.4) \\
60(54.6)\end{array}$ & $\begin{array}{l}13(26.0) \\
12(20.0)\end{array}$ & 0.60 \\
\hline $\begin{array}{l}\text { Knowledge about parasite } \\
\text { Yes } \\
\text { No }\end{array}$ & $\begin{array}{l}78(70.9) \\
32(29.1)\end{array}$ & $\begin{array}{l}23(29.5) \\
15(46.9)\end{array}$ & 0.12 & $\begin{array}{l}85(77.3) \\
25(22.7)\end{array}$ & $\begin{array}{l}18(21.2) \\
7(28.0)\end{array}$ & 0.65 \\
\hline $\begin{array}{l}\text { Knowledge about transmission, control and prevention } \\
\text { Yes } \\
\text { No }\end{array}$ & $\begin{array}{l}50(45.4) \\
60(54.6)\end{array}$ & $\begin{array}{l}13(26.0) \\
25(41.7)\end{array}$ & 0.12 & $\begin{array}{l}70(63.6) \\
40(36.4)\end{array}$ & $\begin{array}{l}14(20.0) \\
11(27.5)\end{array}$ & 0.50 \\
\hline $\begin{array}{l}\text { Opinion on effect of dirty water causing illness } \\
\text { Yes } \\
\text { No }\end{array}$ & $\begin{array}{l}72(65.4) \\
38(34.6)\end{array}$ & $\begin{array}{l}24(33.3) \\
14(36.8)\end{array}$ & 0.87 & $\begin{array}{l}80(72.7) \\
30(27.3)\end{array}$ & $\begin{array}{ll}17 & (21.2) \\
8 & (26.7)\end{array}$ & 0.72 \\
\hline $\begin{array}{l}\text { Hand washing before and after meal } \\
\text { Yes } \\
\text { No }\end{array}$ & $\begin{array}{l}85(77.3) \\
25(22.7)\end{array}$ & $\begin{array}{l}25(29.4) \\
13(52.0)\end{array}$ & 0.06 & $\begin{array}{l}91(82.7) \\
19(17.3)\end{array}$ & $\begin{array}{l}18(19.8) \\
7 \quad(36.8)\end{array}$ & 0.18 \\
\hline $\begin{array}{l}\text { Hand washing after defecation } \\
\text { Yes } \\
\text { No }\end{array}$ & $\begin{array}{l}85(77.3) \\
25(22.7)\end{array}$ & $\begin{array}{l}24(28.2) \\
14(56.0)\end{array}$ & 0.01 & $\begin{array}{l}91(82.7) \\
19(17.3)\end{array}$ & $\begin{array}{l}15(16.5) \\
10(52.6)\end{array}$ & 0.001 \\
\hline $\begin{array}{l}\text { Hand washing with } \\
\text { Water only } \\
\text { Soap } \\
\text { Ash } \\
\text { Mud and soil }\end{array}$ & $\begin{array}{l}11(12.9) \\
17(20.0) \\
31(36.5) \\
26(30.6)\end{array}$ & $\begin{array}{ll}4 & (36.4) \\
2 & (11.8) \\
6 & (19.3) \\
12 & (46.1)\end{array}$ & 0.04 & $\begin{array}{l}10(10.9) \\
60(65.9) \\
11(12.3) \\
10(10.9)\end{array}$ & $\begin{array}{l}3(30.0) \\
6(10.0) \\
2(18.2) \\
4(40.0)\end{array}$ & 0.06 \\
\hline $\begin{array}{l}\text { Opinion on hand washing with soap } \\
\text { Remove germs } \\
\text { Prevent illness } \\
\text { Clean hand }\end{array}$ & $\begin{array}{l}32(29.1) \\
28(25.4) \\
50(45.5)\end{array}$ & $\begin{array}{l}10(31.2) \\
9 \quad(32.1) \\
19(38.0)\end{array}$ & 0.78 & $\begin{array}{l}47(42.7) \\
40(36.4) \\
23(20.9)\end{array}$ & $\begin{array}{ll}10 & (21.3) \\
8 & (20.0) \\
7 & (30.4)\end{array}$ & 0.60 \\
\hline $\begin{array}{l}\text { Drinking water quality } \\
\text { Filtered } \\
\text { Direct water }\end{array}$ & $\begin{array}{l}30(27.3) \\
80(72.7)\end{array}$ & $\begin{array}{l}8(26.7) \\
30(37.5)\end{array}$ & 0.40 & $\begin{array}{l}50(45.4) \\
60(54.6)\end{array}$ & $\begin{array}{l}10(20.0) \\
15(25.0)\end{array}$ & 0.69 \\
\hline $\begin{array}{l}\text { Defecation sites } \\
\text { Toilet } \\
\text { Open place }\end{array}$ & $\begin{array}{l}35(31.8) \\
75(68.2)\end{array}$ & $\begin{array}{ll}6 & (17.1) \\
32 & (42.7)\end{array}$ & 0.01 & $\begin{array}{l}95(86.4) \\
15(13.6)\end{array}$ & $\begin{array}{r}19(20.0) \\
6(40.0)\end{array}$ & 0.09 \\
\hline $\begin{array}{l}\text { Habit of walking bare foot } \\
\text { Never } \\
\text { Sometimes } \\
\text { Frequently }\end{array}$ & $\begin{array}{l}10(9.09) \\
40(36.36) \\
60(54.56)\end{array}$ & $\begin{array}{l}1(10.0) \\
8(20.0) \\
29(48.3)\end{array}$ & 0.003 & $\begin{array}{l}15(13.6) \\
55(50.0) \\
40(36.4)\end{array}$ & $\begin{array}{l}1(6.7) \\
9(16.7) \\
15(37.5)\end{array}$ & 0.01 \\
\hline $\begin{array}{l}\text { Consumption of raw vegetables } \\
\text { Yes } \\
\text { No }\end{array}$ & $\begin{array}{l}60(54.5) \\
50(45.5)\end{array}$ & $\begin{array}{l}22(36.0) \\
16(32.0)\end{array}$ & 0.75 & $\begin{array}{l}53 \\
57\end{array}$ & $\begin{array}{l}13(24.5) \\
12(21.0)\end{array}$ & 0.83 \\
\hline $\begin{array}{l}\text { Consumption of raw or undercooked meat } \\
\text { Yes } \\
\text { No }\end{array}$ & $\begin{array}{l}90(81.8) \\
20(18.2)\end{array}$ & $\begin{array}{l}32(35.5) \\
6(30.00)\end{array}$ & 0.83 & $\begin{array}{l}80(72.7) \\
30(27.3)\end{array}$ & $\begin{array}{l}19(23.7) \\
6(20.01)\end{array}$ & 0.87 \\
\hline
\end{tabular}


defecation in both communities $(\mathrm{P}<0.05)$. The result was similar to various national and international works $[25,33$, 46-48]. This might be because most of the helminth parasites have fecal-oral-route of transmission and proper handwashing can remove the infective stages that might present in hands and prevent the transmission of parasites through this route. On the use of handwashing agents after defecation, a significantly high prevalence of parasitic infection was encountered in people of the Satar community who used to use mud and soil as a handwashing agent. The result showed agreement with research done in other communities too, both nationally and internationally [24, 47]. This high prevalence of the parasite in people who used soil and mud as a handwashing agent might be due to further contamination of their hands with parasites instead of removing them. A significantly high prevalence of parasite was seen among those who defecate in open places in the Satar community $(\mathrm{P}<0.05)$. The high rate of parasitic infection among open place defecators was observed in the systematic review and data analysis of other workers too $[64,65]$. In the present study, a significant association was seen between barefoot walking habits and the prevalence of parasites in both communities $(\mathrm{P}<0.05)$. The result is in agreement with the works of others which showed a significant association between barefoot walking habit and parasitic infection $[47,66]$. This high infection of parasites in barefoot walking people might be due to the entrance of the infective stage (larvae) of parasites through soft parts. The significant association of barefoot walking habit and infection of parasites in both communities suggests that this is one of the major risk factors of infections.

\section{CONCLUSION}

A remarkably high prevalence of intestinal helminth infection was seen in Satar and Chaudhary communities of Birtamode Municipality. The prevalence of intestinal parasite was found to be $28.63 \%$ overall. A significant difference in the prevalence of parasites between two communities shows the difference in their living habit and hygiene practices. The higher rate of infection among children shows poverty, illiteracy, lack of awareness, unhygienic behavior, and lack of sanitation in the study area. The marginally high infection rate among males shows gender independence of parasitic infection. $A$. lumbricoides was the most prevalent parasite. In risk factor analysis, statistically significant associations were seen between the prevalence of parasites and handwashing habits after defecation, handwashing agent, defecation site preference, and barefoot walking habit in the Satar community. In the Chaudhary community, hands washing habits after defecation and barefoot walking habits are the risk factors that showed significant association with parasitic infections. Hence, a remarkable prevalence of parasitic infection was indicated by the present study. Improvements in personal hygiene practices, environmental sanitation, provision of sanitary toilets, provision of awareness programs, and preven- tive measure implementation are important to overcome the parasitic infection in these communities.

\section{CONFLICT OF INTEREST}

Declared none.

\section{ACKNOWLEDGEMENTS}

We are very thankful to Satar and Chaudhary communities of Birtamode municipality for their co-operation during work in that area. Our sincere gratitude to all the staffs of the Central Department of Zoology, Tribhuvan University.

\section{REFERENCES}

[1] Suntaravitun P, Dokmaikaw A. Prevalence of intestinal protozoan infections among School children in Bang Khla District, Chachoengsao Province, Central Thailand. Asian Pacific J Trop Dis 2018; 7(9): 523-26.

DOI: 10.12980/apjtd.7.2017D7-142

[2] Harhay MO, Horton J, Olliaro PL. Epidemology and control of human gastrointestinal parasites in children. Expert Rev Anti-infect Therapy 2010; 8(2): 219-34.

DOI: $10.1586 /$ eri.09.119

[3] Saboya MI, Catala L, Nicholls RS, Ault SK. Update on the mapping of prevalence and intensity of infection for soil transmitted helminth infections in Latin America and Caribbean: A call for action. Publ Library Sci Trop Dis 2013; 7(9): 2419-58. DOI: 10.1371/journal.pntd.0002419

[4] WHO. Soil Transmitted Helminths Infection, Fact sheet. World Health Organization, Geneva 2017.

[5] Amare B, Ali J, Moges B, et al. Nutritional status, intestinal parasite infection and allergy among school children in Northwest Ethiopia. Bio Med Central Pediatr 2013; 13 : 7.

DOI: $10.1186 / 1471-2431-13-7$

[6] Legesse M, Erko B. Prevalence of intestinal parasites among school children in a rural area close to the Southeast of Lake Langano, Ethiopia. Ethiop J Health Dev 2004; 18(2): 116-20. DOI: $10.4314 /$ ejhd.v18i2.9947

[7] Rinne S, Rodas EJ, Galer-Unti R, Glickman N, Glickman LT. Prevalence and risk factors for protozoan and nematode infections among children in an Ecuadorian Highland Community. Trans R Soc Trop Med Hygiene 2005; 99(8): 585-92. DOI: 10.1016/j.trstmh.2005.01.003

[8] Wordemann M, Polman K, Menocal HLT, et al. Prevalence and risk factors of intestinal parasites in Cuban children. Trop Med Int Health 2006; 11(12): 1813-20.

DOI: $10.1111 /$ j.1365-3156.2006.01745.x

[9] Munoz-Antoli C, Pavón A, Marcilla A, Toledo R, Esteban J. Prevalence and risk factors related to intestinal parasites among children in department of Rio San Juan, Nicaragua. Trans R Soc Trop Med Hygiene 2014; 108(12): 774-82. 
DOI: $10.1093 / \operatorname{trstmh} / \operatorname{tru} 160$

[10] Amuta E, Houmsou R, Mker S. Knowledge and risk factors of intestinal parasitic infections among women in Makurdi, Benue State. Asian Pac J Trop Med 2010; 3(12): 993-96. DOI: 10.1016/S1995-7645(11)60016-3

[11] Ngui R, Ishak S, Chuen CS, Mahmud R, Lim YA. Prevalence and risk factors of intestinal parasitism in rural and remote west Malaysia. PloS Neglect Trop Dis 2011; 5(3): e974. DOI: $10.1371 /$ journal.pntd.0000974

[12] Al-Shammari S, Khoja T, El-Khwasky F, Gad A. Intestinal parasitic diseases in Riyadh, Saudi Arabia: Prevalence, sociodemographic and environmental associates. Trop Med Int Health 2001; 6(3): 184-9.

DOI: $10.1046 / j .1365-3156.2001 .00698 . x$

[13] Gelaw A, Anagaw B, Nigussie B, et al. Prevalence of intestinal parasitic infections and risk factors among school children at the university of Gondar community school, Northwest Ethiopia: A cross-sectional study. BMC Public Health 2013; 13: 304. DOI: $10.1186 / 1471-2458-13-304$

[14] Dwivedi KK, Prasad G, Saini S, Mahajan S, Lal S, Baveja UK. Enteric opportunistic parasites among hiv infected individuals: Associated risk factors and immune status. Jpn J Infect Dis 2007; 60(2): 76-81.

[15] Tuli L, Gulati AK, Sundar S, Mohapatra TM. Correlation between CD4 counts of HIV patients and enteric protozoan in different seasons: An experience of a tertiary care hospital in Varanasi, India. BMC Gastroenterol 2008; 8: 36.

DOI: $10.1186 / 1471-230 \mathrm{X}-8-36$

[16] Ahmed A, Al-Mekhlafi HM, Choy SH, et al. The burden of moderate-to-heavy soil-transmitted helminth infections among rural Malaysian aborigines: An urgent need for an integrated control programme. Parasit Vectors 2011; 4: 242. DOI: $10.1186 / 1756-3305-4-242$

[17] Nasr NA, Al-Mekhlafi HM, Ahmed A, Roslan MA, Bulgiba A. Towards an effective control programme of soil-transmitted helminth infections among Orang Asli in rural Malaysia. Parasit Vectors 2013; 6: 28. DOI: 10.1186/1756-3305-6-28

[18] Al-Delaimy AK, Al-Mekhlafi HM, Nasr NA, et al. Epidemiology of intestinal polyparasitism among Orang Asli school children in rural Malaysia. PloS Neglect Trop Dis 2014; 8(8): e3074. DOI: 10.1371/journal.pntd.0003074

[19] Ngui R, Aziz S, Chua KH, et al. Patterns and risk factors of soil-transmitted helminthiasis among Orang Asli subgroups in peninsular Malaysia. Am J Trop Med Hyg 2015; 93(2): 361-70. DOI: 10.4269/ajtmh.13-0677

[20] Lim YAL, Romano N, Colin N, Chow SC, Smith HV. Intestinal parasitic infections amongst Orang Asli (Indigenous) in Malaysia: Has socioeconomic development alleviated the problem? Trop Biomed 2009; 26(2): 110-22.
[21] Lee SC, Ngui R, Tan TK, Muhammad AR, Lim YAL. Neglected tropical diseases among two indigenous subtribes in peninsular Malaysia: Highlighting differences and co-infection of helminthiasis and sarcocystosis. PloS One 2014; 9(9): e107980. DOI: 10.1371/journal.pone.0107980

[22] Khanal M. Prevalence of intestinal parasites in Tharu and muslim community of Chanal VDC, Kapilvastu District, Nepal. M. Sc. Thesis. Central Department of Zoology, Tribhuvan University, Kathmandu Nepal 2005.

[23] Sah AK. Prevalence of intestinal parasites among Tharu Community of Rajhena VDC, Banke, Nepal. M. Sc. Thesis. Central Department of Zoology, Tribhuvan University, Kathmandu, Nepal 2012.

[24] Dhakal N. Prevalence of intestinal parasites in Meche community of Jalthal Nepal in relation to their socio-economic status. M. Sc. Thesis. Central Department of Zoology, Tribhuvan University, Kathmandu, Nepal 2018.

[25] Parajuli RP. Prevalence of intestinal parasites in Mushahar community of Chitwan District in relation to their socio-cultural and socio-economic status. M. Sc. Thesis. Central Department of Zoology, Tribhuvan University, Kathmandu, Nepal 2003.

[26] Pokharel YB. Epidemiology and control strategy of intestinal parasites among Chepang children $(<16$ years) at Taklung VDC of Gorkha. M.Sc. Thesis. Central Department of Zoology, Kathmandu, Nepal 2005.

[27] Jha PC. Prevalence of intestinal parasite with respect to socio-economic aspect in dom community of Janakpur Municipality, Dhanusha. M. Sc. Thesis. Central Department of Zoology, Tribhuvan University, Kathmandu, Nepal 2017.

[28] Yadav K, Prakash S. Study of intestinal parasitosis among schoolchildren of Kathmandu valley, Nepal. Asian J Biomed Pharmaceut Sci 2016; 6(59): 40-5.

[29] Central Bureau of Statistics. National Population and Housing Census 2011: National Report. 2012; Vol. 1. Available at : https://unstats.un.org/unsd/demographic-social/census/documents/Nepal/Nepal-Census-2011-Vol1.pdf

[30] Chatterjee KD. Parasitology: Protozoology and Helminthology. $13^{\text {th }}$ ed. New Delhi, India: CBS Publishers and Distributors, Prahlad Street 2017.

[31] CDC. Laboratory Identification of Parasites of Public Health Concern 2017; Available: https://www.cdc.gov/dpdx/hymenolepiasis/index.html

[32] Viney ME, Lok JB. The biology of Strongyloides spp. WormBook: The Online Review of C. elegans Biology. Pasadena (CA): WormBook 2018. https://www.ncbi.nlm.nih.gov/books/NBK19795/ 
[33] Nitin S, Venkatesh V, Husain N, Masood J, Agrawa GG. Overview of intestinal parasitic prevalence in rural and urban population in Lucknow, North India. J Commun Dis 2007; 39(4): 217-23.

[34] Khanal LK, Rai SK, Khanal PR, Ghimire G. Status of intestinal parasitosis among hospital visiting patients in Deukhury Valley, Dang. Nepal Med Coll J 2011; 13(2): 100-2.

[35] Verle P, Kongs A, De NV, et al. Prevalence of intestinal parasitic infections in northern Vietnam. Trop Med Int Health 2003; 8(10): 961-4. DOI: 10.1046/j.1365-3156.2003.01123.x

[36] Mehraj V, Hatcher J, Akthar S, Rafique G, Beg MA. Prevalence and factors associated with intestinal parasitic infections among children in Urban Slum of Karachi. PloS One 2008; 3(11): e3680. DOI: 10.1371/journal.pone.0003680

[37] Dhanabal J, Selvados PS, Muthuswamy K. Comparative study of prevalence of intestinal parasites in low socio-economic area from South Chennai, India. J Parasitol Res 2014; 2014 : Article ID 630968. DOI: 10.1155/2014/630968

[38] Nyantekyi L, Legesse M, Medhin G, et al. Community awareness of intestinal parasites and prevalence of infection among community members of rural Abaye Deneba area, Ethiopia. Asian Pac J Trop Med 2014; 4(1): 152-7. DOI: 10.12980/APJTB.4.2014C764

[39] Chongbang R, Dangol P, Chakrawarthi A, Khanal, H. Parasitic infections among children of squatter community in Dharan Municipality, Sunsari, Nepal. Int J Appl Sci Biotechnol 2016; 4(2): 203-6. DOI: 10.3126/ijasbt.v4i2.15099

[40] Bahrami F, Haghighi A, Zamini G, Khadem-Erfan MB, Azargashb E. Prevalence and associated risk factors of intestinal parasitic infections in Kurdistan Province, Northwest Iran. Congenit Med 2018; 5(1): 1503777. DOI: 10.1080/2331205X.2018.1503777

[41] Shrestha A, Schindler C, Odermatt P, Gerold J, Erismann S, Sharma S. Intestinal parasitic infections and associated risk factors among schoolchildren in Dolakka and Ramechhap District, Nepal: A cross sectional study. Parasit Vectors 2018; 11(1): 532. DOI: 10.1186/s13071-018-3105-0

[42] Poudel D, Aung MN, Sharma B, Aung TNN, Moolphate S. Intestinal parasitic infections in combatants and their families: A hospital based study in midwestern regional police hospital, Nepal. Global J Health Sci 2014; 6(3): 9-15. DOI: $10.5539 /$ gjhs.v6n3p9

[43] Ishimaya S, Rai SK, Ono K, Uga S. Small scale study on intestinal parasitosis in a remote hilly village in Nepal. Nepal Med Coll J 2003; 5(1): 28-30.

[44] Shakya B, Rai SK, Singh A, Shrestha A. Intestinal parasitosis among the elderly people in Kathmandu Valley. Nepal Med Coll J 2006; 8(4): 243-7.

[45] Childers K, Palmeri JR, Sampson M, Brunet D. Prevalence of gastrointestinal parasites in children from Veron, a rural city of Dominican Republic. Res Rep Trop Med 2014; 5: 45-53. DOI: 10.2147/RRTM.S64948

[46] Regmi P, Rai KR, Mukhiya RK et al. Prevalence of intestinal parasites and associated risk factors among school children of Kalaiya, Bara District, Nepal. J Sci Med Microbiol 2014; 2(1): 1009.

[47] Elyana FN, Al-Mekhlafi HM, Jthoi I, et al. A tale of two communities: Intestinal polyparasitism among Orang Asli and Malay communities in rural Terengganu, Malaysia. Parasit Vectors 2016; 9(1): 398. DOI: 10.1186/s13071-016-1678-z

[48] Punsawad C, Phasuk N, Bunratsami S, et al. Prevalence of intestinal parasitic infections and associated risk factors for hookworm infection among primary schoolchildren in rural area of Nakhon Si Thammarat, Southern Thailand. BMC Public Health 2018; 18(1): 1118.

DOI: $10.1186 / \mathrm{s} 12889-018-6023-3$

[49] Shrestha B. Intestinal parasitic infestation in healthy school children of Lalitpur district. J Nepal Med Assoc 2001; 41(141): 266-70. DOI: 10.31729/jnma.743

[50] Rai SK, Hirai K, Abe A, et al. Study on enteric parasitosis and nutritional status of school children in remote hilly areas in Nepal. Nepal Med Coll J 2004; 6(1): 1-6.

[51] Rai DR, Rai SK, Sharma BK, Ghimire P, Bhatta DR. Factors associated with intestinal parasitic infection among school children in a rural area of Kathmandu Valley, Nepal. Nepal Med Coll J 2005; 7(1): 43-6.

[52] Gyawali N, Amatya R, Nepal HR. Intestinal parasitosis in school going children of Dharan Municipality. Nepal Trop Gastroenterol 2009; 30(3): 145-7.

[53] Pradhan P, Bhandary S, Shakya PR, Acharya T, Shrestha A. Prevalence of intestinal parasitic infections among public school children in a rural village of Kathmandu Valley. Nepal Med Coll J 2014; 16(1): 50-3.

[54] Champetier de Ribes G, Fline M, Desormeaux AM, et al. Intestinal helminthiasis in school children in Haiti. in 2002. Bull Soc Pathol Exot 2002; 98(2): 127-32.

[55] Rai SK, Bajracharya K, Budhathoki S, et al. Status of intestinal parasitosis at TU teaching hospital. J Inst Med 1995; 17: 134-40.

[56] Sinniah B, Rajeswar B. Economic status associated with intestinal nematode infections. Asian Parasit Control Org 1998; 98: 71-7.

[57] Rai SK, Matsumara T, Ono K. Intestinal parasitosis in an "unknown disease outbreak" hit rural hilly area in western Nepal. Nepal Med Coll J 2000; 2: 61-4.

[58] Rai CK, Shrestha A, Shah RDP, Rai SK. Study of intestinal parasitosis among patients visiting health care centre in 
Kathmandu Valley. J Nepal Assoc Lab Med Sci 2007; 8: 33-6.

[59] Collins RF, Edwards LD. Prevalence of intestinal helminths and protozoans in a rural population segment of the dominican republic. Trans R Soc Trop Med Hygiene 1981; 75(4): 549-51. DOI: $10.1016 / 0035-9203(81) 90196-6$

[60] Sharma BK, Rai SK, Rai DR, Choudhury DR. Prevalence of intestinal parasitic infections in schoolchildren in northwestern part of Kathmandu Valley, Nepal. Southeast Asian J Trop Med Public Health 2004; 55(3): 501-5.

[61] Shrestha A, Rai SK, Basnyat SR, Rai CK, Shakya B. Soil transmitted helminthiasis in Kathmandu, Nepal. Nepal Med Coll J 2007; 9(3): 166-9.

[62] Estevez EG, Levine JA, Warren J. Intestinal parasites in a remote village in Nepal. J Clin Microbiol 1983; 17(1): 160-1. DOI: $10.1128 / J C M .17 .1 .160-161.1983$
[63] Sherchand JB, Ohara H, Sherchand S, Cross JH, Shrestha MP. Intestinal parasitic infections in rural areas of Southern Nepal. Inst Med J Nepal 1997; 19: 115-21.

[64] Ziegelbauer K, Speich B, Mausezahl D, Bos R, Keiser J, Utzinger J. Effect of sanitation on soil transmitted helminth infection: Systematic review and meta-analysis. PloS Med 2012; 9(1): 5. DOI: 10.1371/journal.pmed.1001162

[65] Schmidlin T, Hurlimann E, Silue KD, et al. Effect of hygiene and defecation behaviour on helminths and intestinal protozoa infection in Taabo, Cote D'Ivore. PloS One 2013; 8(6): e65722. DOI: 10.1371/journal.pone.0065722

[66] Sah RB, Pokharel PK, Poudel IS, Acharya A, Jha N. A study of prevalence of worm infestation and associated risk factor among the school children of Dharan, Eastern Region of Nepal. Int J Med Dent Sci 2013; 2(2): 121-7. DOI: $10.19056 /$ ijmdsjssmes/2013/v2i2/86766 